DOI:10.17951/h.2019.53.1.77-88

\begin{tabular}{lc}
\hline & A N N A L E S \\
UNIVERSITATIS & MARIAE CURIE-SKŁODOWSKA \\
LUBLIN - POLONIA & SECTIO H \\
VOL. LIII, 1 & 2019 \\
\hline
\end{tabular}

\author{
MAGDALENA SOBOCIŃSKA \\ magdalena.sobocinska@ue.wroc.pl \\ Wrocław University of Economics, Komandorska 118/120, 53-205 Wrocław, Poland \\ ORCID ID: https://orcid.org/0000-0002-5231-2511
}

\title{
Marketing resources in the processes of competing in the era of the virtualisation of socio-economic life
}

Keywords: marketing resources; the process of competing; new information and communication technologies; virtualisation of socio-economic life

JEL: D1; D4; M15; M3

How to quote this paper: Sobocińska, M. (2019). Marketing resources in the processes of competing in the era of the virtualisation of socio-economic life. Annales Universitatis Mariae Curie-Skłodowska, sectio H-Oeconomia, Vol. 53, No. 1.

\begin{abstract}
Theoretical background: The growing scope of virtualisation of consumer behaviour and the emergence of new business models associated with it has caused changes in the approach to the processes of the competing and management of company resources. This is accompanied by the growing importance of the customer in each stage of the value management process. In this context, a question is raised concerning the significance of marketing resources in the processes of competing between enterprises. At the same time, it should be noted that nowadays, marketing is becoming one of the business functions associated to the highest possible extent with information technology. These changes are demonstrated by the creation of a new managerial specialisation, i.e. a manager for marketing technologies who creates the technological image of marketing development. The objective of the management in the sphere of marketing technology is to create the value spiral, in which what is possible in the sphere of technology will be an inspiration for what is indicated in the sphere of marketing, and vice versa.

Purpose of the article: The purpose of the paper is to demonstrate the significance of marketing resources, with a special focus on marketing knowledge, in the processes of competing between enterprises in the era of new media.
\end{abstract}


Research methods: The paper is based on the analysis of secondary sources, the basis of which are in-depth studies of the literature in the sphere of marketing and new media, reports from research concerning digitalisation on a micro and macro scale, and consequences resulting from these processes.

Main findings: The conducted survey of the literature indicates that marketing resources play a vital role in the processes of competing between enterprises. It further demonstrates that categories such as marketing knowledge, brand and relationships with entities of the environment are characterised by limited substitutability, the imperfect ability to be imitated and big value. Therefore, according to the resource theory, enterprises determine the gaining of competitive advantage by an entity. At the same time, new information and communication technologies are having an increasingly bigger impact on the growth of marketing resources. This is especially notable in the area of the enhancement of relationships with customers or marketing knowledge management, because new technologies find application at the stage of acquisition, popularisation and application of knowledge in the processes of marketing decision-making, which are translated into a competitive position achieved by the entity. Furthermore, the relationship between marketing and new technologies is expressed in terms of the increase of the scope of product individualisation and marketing communication.

\section{Introduction}

Changeability and the complex behaviours of market entities bring changes to the ways in which enterprises compete. New technologies play an important role in these processes, as the scope of their use is growing. This is accompanied by the increasing importance of the customer, who is becoming a value co-creator, at individual stages of value management. In this context, it seems relevant to investigate the significance of marketing resources in the process of competition between enterprises.

Showing competing processes in the era of the virtualisation of socio-economic life requires reference to the notion of technological determinism. Analysis of the literature in this field shows that the so-called soft and hard forms of technological determinism can be distinguished (Smith \& Marx, 1994; MacKenzie \& Wajcman, 1999). The former means that technology is one of several determinants of changes occurring in the society and economy. On the other hand, according to hard form of technological determinism, the observed changes mainly result from technology development, whereas other development factors are less important. However, it must be noted at the same time that, regardless of what form of technological determinism is considered the leading one, it should be nonetheless agreed that technology implementation brings changes that go considerably beyond the framework of its functioning. This concerns social changes and economic changes in the macro-economic approach, as well as in terms of the functioning of enterprises and consumer behaviours (Mącik, 2013, pp. 25-52). Furthermore, this is notable at individual stages of the development of information and communication technology, including the computer era, PC era, communication era, co-creation era, automation era and transformation era, in which the transformation of physical market into sets of data occurs (Mazurek, 2019, pp. 25-27). The observed data explosion forms new challenges for the functioning and competing of enterprises (Lipowski \& Bondos, 2016, pp. 520-529). 
The purpose of the paper is to demonstrate the importance of marketing resources with a special focus on marketing knowledge in the processes of competing between enterprises in the era of new media development. Its implementation requires presentation of the ways in which marketing resources are conceptualised, and which are found in the literature, whereas their role in competing processes is determined with reference to the resource theory of enterprise and occurring processes of digitalisation that are approached from the perspective of enterprise competitiveness as well as economy. Special attention is focused on the virtualisation of marketing operations and the application of new technologies in the creation of marketing knowledge as an enterprise resource.

\section{Methods of conceptualisation of marketing resources and their significance in competing processes - literature review}

On the basis of the performed analysis of the literature, it is clear that marketing resources are defined in the context of material and non-material elements of the market entity and its environment. They can be applied by the enterprise to influence the target market. It should also be emphasised that marketing resources emerge in the marketing process and find application together with other resources in the establishment of competitive advantage. The classification of marketing resources identifies relationship and intellectual resources, material, non-material, external, customer-, distribution- and alliance-related marketing resources. Methods of the conceptualisation of marketing resources in the literature are shown in Table 1.

Any identification of the role of marketing resources in the competing process should emphasise that its stages include competitive potential, competitiveness management and competing results (Buckley et al., 1988, pp. 175-200). Competitive potential is the starting point in the competing process. This potential is affected in the process of competitiveness management for the purpose of the achievement of specific competing results. Specific relationships occur between the three distinguished aspects of competing. On the one hand, competitive potential should be approached as a set of determinants influencing the way in which competitiveness is managed, whereas the process of competitiveness management shapes the quality and size of competitive potential. Furthermore, the achieved results of competition also have an impact on the quality and size of competitive potential and the way in which competitiveness is managed (Gorynia, 2009, pp. 56-58, 65).

Creators of the resource theory of the enterprise emphasise that not all resources determine the sustained competitive advantage of a market entity, but only those that have the features described through the prism of their value, scarceness, imperfect imitability and limited substitutability (Barney, 1991, pp. 105-106). Indicated attributes well describe marketing resources; and their importance as sources of value is growing. Marketing has a vital contribution in the creation of value not only for 
the buyer but also the enterprise, whereas such categories as marketing knowledge, brand or relationships with entities of the environment are becoming increasingly more important in competing processes.

Table 1. Concepts and types of marketing resources

\begin{tabular}{|c|c|}
\hline $\begin{array}{l}\text { Author of the } \\
\text { approach }\end{array}$ & Concepts of marketing resources \\
\hline A. Czubała & $\begin{array}{l}\text { Marketing resources are constituted by the company name and its image, possessed brands, } \\
\text { distinctive products, market position, unique character and efficiency of distribution, } \\
\text { communication system, access to technology, information system, copyrights and patents, } \\
\text { alliances and management culture. Together with competences and marketing skills, these } \\
\text { resources form value carriers. The list of marketing resources is open. }\end{array}$ \\
\hline $\begin{array}{l}\text { G. Hooley, } \\
\text { J. Saunders, } \\
\text { N. Piercy }\end{array}$ & $\begin{array}{l}\text { Marketing resources are divided into customer-related, distribution-related, alliances-related } \\
\text { and external resources. Resources related to the customer have both a material and non-ma- } \\
\text { terial nature. This group of resources includes such categories as the name, possessed } \\
\text { brands, country of origin, distinctive products and services, and market predominance. Ex- } \\
\text { ternal resources comprise cost advantage, information system, marketing knowledge, cus- } \\
\text { tomer database, technological skills, production experience, copyrights, patents, contracts, } \\
\text { licences and the culture of the market entity. Resources related to distribution include the } \\
\text { distribution network, its unique character, distribution control, time and security of supplies } \\
\text { and chain of suppliers. On the other hand, access to the market and technology, exclusive } \\
\text { rights and management capability can be achieved thanks to developed alliances. }\end{array}$ \\
\hline R. Niestrój & $\begin{array}{l}\text { Material and non-material elements of market entity and its environment that can be applied } \\
\text { in its influence on the target market. Marketing assets are controlled by market entity. They } \\
\text { include marketing instruments, reputation, share in the market, brand prestige and image. }\end{array}$ \\
\hline $\begin{array}{l}\text { R. Srivastava, } \\
\text { T. Shervani, } \\
\text { L. Fahey }\end{array}$ & $\begin{array}{l}\text { There are two groups of marketing resources that are mutually complementary and interde- } \\
\text { pendent, i.e. relationship marketing resources and intellectual marketing resources. Rela- } \\
\text { tionship resources emerge as a result of relationships created by the market entity with other } \\
\text { entities of the environment, including buyers, intermediaries, business partners, local com- } \\
\text { munities and government agendas. Intellectual marketing resources are based on knowledge } \\
\text { possessed by the market entity about its environment. Correlations between relationship } \\
\text { and intellectual resources result from the fact that relationships created with market entities } \\
\text { allow knowledge about them to be gained and verified, which facilitates making decisions } \\
\text { concerning the selection of entities with which relationships are maintained. }\end{array}$ \\
\hline $\begin{array}{l}\text { M. Szymura- } \\
\text {-Tyc }\end{array}$ & $\begin{array}{l}\text { Marketing resources are market entity resources that emerge in the marketing process and, } \\
\text { together with other resources, find application in the creation of competitive advantage. } \\
\text { Marketing resources are created by such categories as the system of marketing information, } \\
\text { customer database, relationships with suppliers, brand and image of market entity, and rela- } \\
\text { tionships with distribution channel, as well as relationships with customers. Knowledge that } \\
\text { builds intellectual marketing capital constitutes the basis for the selection of target market } \\
\text { and development of the programme of marketing operations. It also affects the development } \\
\text { of other marketing resources. }\end{array}$ \\
\hline G. Urbanek & $\begin{array}{l}\text { Categories such as brand, reputation, relationships with customers and partners that form } \\
\text { a broad collection of non-material resources together with other resources (e.g. organisa- } \\
\text { tional culture, leadership, human capital) are becoming an increasingly important source of } \\
\text { value creation. }\end{array}$ \\
\hline L. Żabiński & $\begin{array}{l}\text { Marketing resources are all the resources that can be used to achieve the marketing targets } \\
\text { of a market entity. }\end{array}$ \\
\hline
\end{tabular}

Source: Author's own study based on: (Czubała, 2004, p. 19; Hooley et al., 1998, p. 116; Niestrój, 1996, p. 79; Rudawska, 2008, pp. 84-94; Srivastava et al., 1998, pp. 2-18; Szymura-Tyc, 2006, pp. 196-203; Urbanek, 2011, p. 8, 33; Żabiński, 1997, p. 19). 
Considering the high competitive position of companies such as Amazon, Apple, Facebook and Google, it should be indicated that the determinants of their success include:

- development of products based on unique functional features, technological innovations and a strong brand;

- appropriate communication and image capitalisation (e.g. Google vision: Ordering the information about the world; Facebook vision: Connecting the whole world);

- global scope of brand;

- care about company image and its positive public perception;

- deliberate shaping of consumer experiences associated with the use of products thanks to distribution control;

- access to data about customers and its management with the use of behavioural targeting and artificial intelligence;

- attracting and retaining best workers described as talents;

- building relationships with world-class universities such as Stanford, Berkeley and Washington University (Galloway, 2018, pp. 225-248).

The above-mentioned sources of success are integrally associated with marketing and marketing resources. At the same time, it should be noted that competing in the era of the virtualisation of socio-economic life can be analysed not only from the perspective of an enterprise but also economy. In this context, it should be emphasised that the digital economy's development in Poland is somewhat unequal, as demonstrated by the fact that apart from the sectors that have the position of digital leaders, many spheres of socio-economic life are still hardly digitalised. Referring to digitalisation in terms of the share of entities included in individual sectors in GDP generation, it must be noted that digital followers (production, trade and transport) have the largest share in GDP, whereas the share of digital leaders, including the financial and insurance sector, as well as information and communication technologies, is relatively smaller (Novak et al., 2018, p. 13). This proves that the use of new technologies on a larger scale by the entities included in the group of digital followers and digital novices offers the opportunity to increase the competitiveness of the Polish economy. The share of individual sectors in GDP in Poland, including their scope of use of new technologies, is illustrated in Figure 1.

Marketing is one of the business functions that is most associated with information technology. The development of a value spiral, in which what is possible in the sphere of technology will be the inspiration for what is indicated in the sphere of marketing and vice versa, is the goal of technology management. 


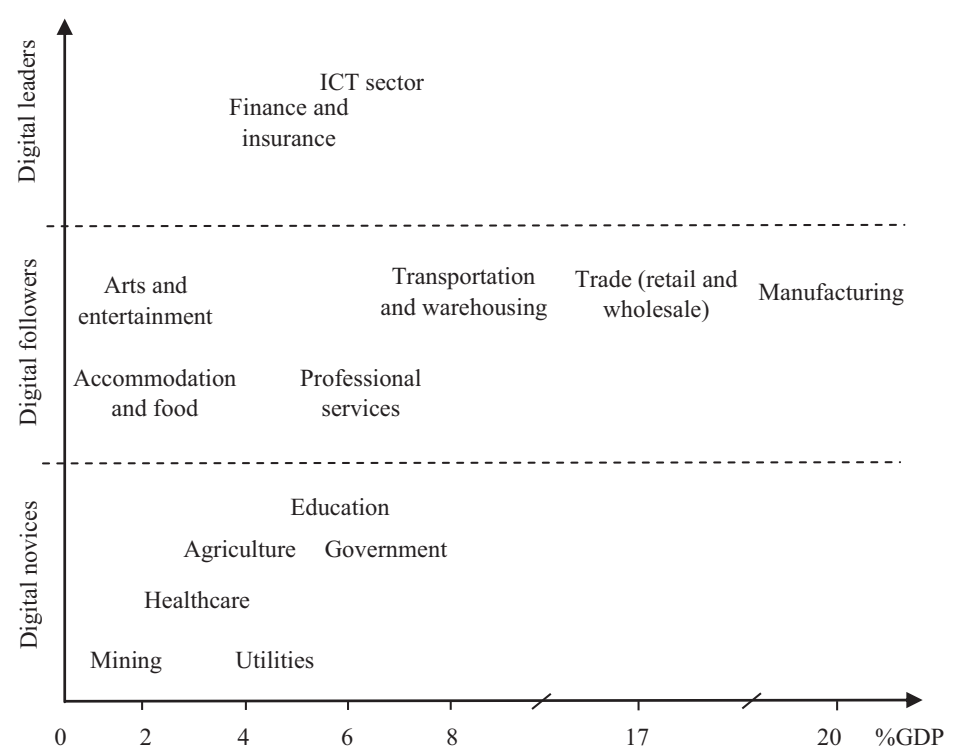

Figure 1. Sector-level digital leaders, followers, and novices in Poland (\% of GDP) Source: (Novak et al., 2018, p. 13).

\section{Virtualisation in marketing in the context of competing processes - results of literature review}

Progress in the use of the Internet is expressed not only in the use of the network in processes of communication with the customer and shaping the image of traditional companies, but primarily in the establishment of companies that provide value to customers with the use of many channels, as well as to online companies. The main sources of income of online businesses include the sale of traditional products and e-services, display of advertisements, sponsoring, commission for intermediation in the execution of transactions, and fees for access to online communities, as well as freemium, perceived as offering the basic product version and the collection of payment for a more advanced one (Doligalski, 2018, pp. 5-22). At the same time, it must be noted that in the business models of online companies, marketing resources play a vital role. They include the created brand that allows the Internet retailers, e-services providers, content suppliers, multilateral trading facilities or creators of communities to stand out and minimise the risk related to the establishment of relationships and online purchase, as experienced by customers.

Here, it should also be relevant to distinguish between company technology and infrastructural technology. Unlike infrastructural technology, company technology is the property of a single company and has proprietary character. Due to this, it can be the source of competitive advantage. On the other hand, infrastructural technologies 
bring much greater benefits if they are applied by many companies. At the same time, it should be stated that in the initial stage of development, infrastructural technology can take the form of company technology (Carr, 2013, pp. 40-41). In competing processes, the innovative application of infrastructural technology seems vital in marketing operations conducted by enterprises.

The attractiveness of the Internet as infrastructural technology for marketing results from the large potential of interactivity that can be approached in the following contexts:

- ability to control the process and participation in the active exchange of value that is network-based and related to the communication between entities;

- the extent of participation of users in modifying the form and content of the environment in which the computer is an intermediary in communication processes;

- the level of engagement of the entities in the process of communication through active and mutual influence;

- the level at which communication is perceived as reciprocal, reacting, fast and characterised by the use of information and which can be controlled by both parties (Mazurek, 2012, pp. 67-68; Johnson et al., 2006, pp. 35-52; Yadav \& Varadarajan, 2005, pp. 585-603).

The large scale of use of new technologies in marketing expands the scope of its virtualisation that can concern communication, distribution and products that are subject to digitalisation. Furthermore, it should be emphasised that the Internet facilitates cooperation with consumers at all stages of the process of management of value for the customer. The considerable possibilities of consumer participation in processes of creation is provided by the mass individualisation of cooperative character, which takes the form of cooperation with customers not only in shaping, but also in defining the value (Peelen, 2005, p. 146). The scope of consumer activity in processes of value creation depends on the level of their engagement, motivation and skills (Mazurek-Łopacińska, 2011, pp. 184-185; Mróz, 2013, pp. 80-81).

The virtualisation of marketing based on solutions presented in Figure 2 allows many benefits to be achieved that are essential for both the consumer and the enterprise. This is because conducting marketing activities on the Internet allows the scope of personalisation of products and marketing messages to be expanded or enables the better use of enterprise resources, for example, through the application of advanced forms of advert targeting.

It should be stated that knowledge that emerges on the basis of the application of artificial intelligence, Internet of Things, or solutions of big data type is of key importance in the creation of competitive advantage based on the virtualisation of marketing. They allow for the improvement of data management in real time. 


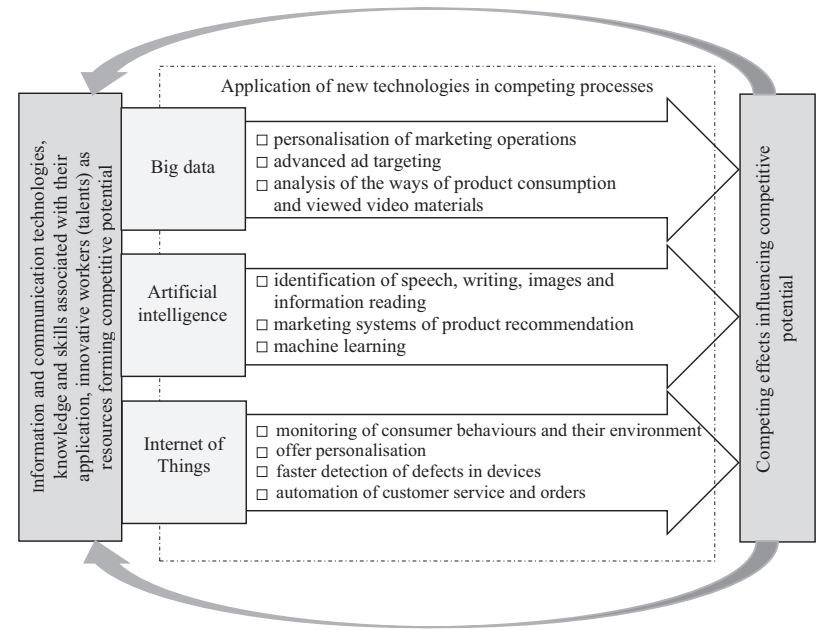

Figure 2. Application of new technologies in marketing and competing processes

Source: Author's own study.

However, the scope of application of these technologies is determined on the one hand, by workers' competences and on the other hand, by customers' acceptability. This is especially important in the context of growing awareness of privacy and Internet users' expectations concerning the protection of their privacy.

\section{New technologies in the creation of marketing knowledge perceived as an enterprise resource}

Technological changes that refer to the system of collecting, processing and diffusing information possess fundamental importance for the transformation of the contemporary world and competing processes (Wiktor, 2018, p. 83).

The development of the scope of use of new technologies has considerable consequences concerning the management of knowledge as an enterprise resource, at the core of which is the fact that the message content gains a new, virtual dimension, and data can be compressed into a small size and processed with greater simplicity and speed than in the case of analogue forms (Lister et al., 2009, p. 18).

The challenges in the sphere of data management and creation of marketing knowledge as an enterprise resource are proved, among other reasons, by the fact that every day Facebook portal users publish nearly 4.5 billion posts, and around 400 hours of video material is uploaded every minute onto YouTube (Lutostański et al., 2018, p. 22).

Marketing research, increasingly more often conducted online, plays a special role in the formation of knowledge as an enterprise resource. It is expressed by the diffusion of various types of Internet panels. Methods such as social network lis- 
tening, netnography and empathic research also find applications in the creation of marketing knowledge (Kotler et al., 2016, pp. 110-113). The monitoring of opinions about the company and products given by customers on the Internet, often with the use of big data, is the essence of social network listening. The monitoring of opinions in a virtual environment in which members of Internet communities feel comfortable, enables the identification of consumer reactions to changes introduced in the offer and the ways in which they are communicated. On the other hand, the application of netnography as an ethnographic method is aimed at understanding human behaviours in virtual communities through their observation. Netnography is a deep immersion in a specific online community, frequently started in the process of social network listening, that helps researchers identify Internet communities who are relevant from the point of view of the research objective. If social network listening is based on specialist software that allows data to be visualised in an automatic way, then netnography requires knowledge and sensibility that allows in-depth reflection to be performed on the subject and the object of the observation. Emphatic research that is close to classical ethnography and consists of interview-supported participant observation and entering the sphere of consumer community for the purpose of the recognition of their needs and attitudes - finds its application in building marketing knowledge.

Attention should also be drawn to the role of systems of deep learning in the creation of marketing knowledge and in processes of new product development. Deep learning technologies read data meaning. They do not need unequivocal algorithms, as the concept of their operation is based on the way in which the human brain works. This is because the systems are modelled in neuron networks functioning in a new human cerebral cortex, in which the cognitive processes of a higher level take place. The most advanced networks of deep learning consist of millions of virtual neurons and billions of their mutual connections. However, the acquisition of big data collection characterised by high quality is still the greatest barrier to the dissemination of these technologies (Singh, 2018/2019, pp. 22-25). There is also a need for a critical assessment of the work of advanced algorithms of deep learning, because current solutions in this sphere are not good enough from the point of view of deduction processes and the formulation of scientific theories. Consequently, this means that knowledge about markets is still incomplete (Blyth, 2018/2019, pp. 25-26). Aiming at the optimal use of technology and human capital in the creation of marketing knowledge, it should be noted that the role of the workers is to develop solutions in the area of artificial intelligence, explain the results of their work and also create conditions for the responsible use of these technological innovations, according to ethical standards.

It must be emphasised that the development of knowledge resources requires the formulation of answers to the questions related to what collected data is useful and what its reliability is. It is also important to determine whether all the collected data finds application in decision-making processes and whether its interpretation results 
in additional information or is just a duplication of already possessed information (Protasiuk \& Karczmarczuk, 2018, p. 23). Due to the fact that there are no ideal sources and methods of data acquisition in knowledge management, the application of triangulation is necessary.

\section{Conclusions}

The conducted literature studies and analyses of reports from research concerning the competitiveness of enterprises and economies reveal that marketing resources, especially marketing knowledge, perform the key role in competing processes. At the same time, it should be noted that the technological progress and Internet transformation that is taking place under the influence of technological changes make many operations and marketing processes subject to virtualisation. This is accompanied by the blurring of boundaries between the enterprise and the environment, and the simultaneous growth of the importance of relationships with customers and network cooperation.

Competing in the era of the virtualisation of socio-economic life requires the development of key competences based on creativity and prompts a reaction to signals coming from the environment. Furthermore, digital competences that play a vital role in competing processes are associated with the knowledge about the mechanisms shaping behaviours of entities occurring in virtual space, especially in social media. Consequently, they enable customer involvement to be expanded and customers to be engaged in actions implemented at individual stages of the value management process. Research and analytical competences that enable the evaluation of data quality and its marketing potential are equally important.

The importance of marketing knowledge as enterprise resource is particularly highlighted in the situation in which, while using several channels and media, the recipient has many points of contact with brand. This makes building relationships with consumers increasingly difficult because the complexity of consumer behaviour is growing.

Furthermore, this paper's findings indicate the need to continue research in the sphere of the discussed subject area. Defining the trends of empirical research, they should aim to diagnose the state of advancement and changes in the scope of the implementation of modern solutions that support knowledge management in various types of market entities, and how this translates into achieved results in competition processes. The studies should consider the sector, the size of the enterprise, the legal form and the level of internationalization of activities. 


\section{References}

Barney, J.B. (1991). Firm resources and sustained competitive advantage. Journal of Management, 17(1). DOI: https://doi.org/10.1177/014920639101700108.

Blyth, S. (2018/2019). Big data i uczenie maszynowe nie ocalą nas przed kolejnym kryzysem finansowym. Harvard Business Review Polska, 12(1).

Buckley, P.J., Pass, C.L., \& Prescott, K. (1988). Measures of international competitiveness: A critical survey. Journal of Marketing Management, 2. DOI: https://doi.org/10.1080/0267257X.1988.9964068.

Carr, N.G. (2013). IT się nie liczy. In: Sztuka tączenia technologii ze strategia. Harvard Business Review Polska. Warszawa: ICAN Institute.

Czubała, A. (2004). Rola marketingu w tworzeniu rynkowej wartości przedsiębiorstwa. In: A. Czubała, R. Niestrój (red.), Finansowe przesłanki decyzji marketingowych. Kraków: Wydawnictwo Akademii Ekonomicznej.

Doligalski, T. (2018). Internet business models in the consumer market - a typological approach. Marketing i Rynek, 12 .

Galloway, S. (2018). Wielka czwórka. Four. Ukryte DNA: Amazon, Apple, Facebook i Google. Poznań: Dom Wydawniczy Rebis.

Gorynia, M. (2009). Teoretyczne aspekty konkurencyjności. In: M. Gorynia, E. Łaźniewska (red.), Kompendium wiedzy o konkurencyjności. Warszawa: Wydawnictwo Naukowe PWN.

Hooley, G., Saunders, J., \& Piercy, N. (1998). Marketing Strategy and Competitive Positioning. UK: Prentice Hall Europe.

Johnson, G.J., Bruner II, G.C., \& Kumar, A. (2006). Interactivity and its facets revisited. Journal of Advertising, 35(4). DOI: http://dx.doi.org/10.2753/JOA0091-3367350403.

Kotler, Ph.,'Kartajaya, H., \& Setiawan, I. (2016). Marketing 4.0: Moving from Traditional to Digital Hardcover. Hoboken: John Wiley \& Sons.

Lipowski, M., \& Bondos, I. (2016). Challenges for service providers under the transformation multi-channeling into omnichanneling. Information Systems in Management, 5(4).

Lister, M., Dovey, J., Giddings, S., Grant, I., \& Kelly, K. (2009). New Media: A Critical Introduction. New York: Routledge.

Lutostański, M.J., Galica, M., \& Protasiuk, M. (2018). Data driven decisions. Jak odnaleźć się w nattoku danych. Warszawa: Wydawnictwo Naukowe PWN.

MacKenzie, D.A., \& Wajcman, J. (1999). The Social Shaping of Technology. Buckingham-Philadelphia: Open University Press.

Mazurek, G. (2012). Znaczenie wirtualizacji marketingu w sieciowym kreowaniu wartości. Warszawa: Wydawnictwo Poltext.

Mazurek, G. (2019). Transformacja cyfrowa. Perspektywa marketingu. Warszawa: Wydawnictwo Naukowe PWN.

Mazurek-Łopacińska, K. (2011). Uczestnictwo w portalach społecznościowych w kontekście zmian zachodzących w konsumpcji i stylu życia Polaków. Handel Wewnętrzny, 3.

Mącik, R. (2013). Technologie informacyjne i komunikacyjne jako moderator procesów podejmowania decyzji zakupowych przez konsumentów. Lublin: Wydawnictwo UMCS.

Mróz, B. (2013). Konsument w globalnej gospodarce. Trzy perspektywy. Warszawa: Oficyna Wydawnicza - Szkoła Główna Handlowa.

Niestrój, R. (1996). Zarządzanie marketingiem. Aspekty strategiczne. Warszawa: Wydawnictwo Naukowe PWN.

Novak, J., Purta, M., Marciniak, T., Ignatowicz, K., Rozenbaum, K., \& Yearwood, K. (2018). The Rise of Digital Challengers. How Digitization Can Become the Next Growth Engine for Central and Eastern Europe. Perspective on Poland. Digital McKinsey.

Peelen, E. (2005). Customer Relationship Management. UK: Prentice Hall. 
Protasiuk, M., \& Karczmarczuk, A. (2018). Strategia marketingowa. In: M.J. Lutostański, M. Galica, M. Protasiuk (red.), Data driven decisions. Jak odnaleźć się w nattoku danych. Warszawa: Wydawnictwo Naukowe PWN.

Rudawska, E. (2008). Znaczenie relacji z klientami w procesie ksztattowania wartości przedsiębiorstwa. Szczecin: Wydawnictwo Naukowe Uniwersytetu Szczecińskiego.

Singh, A. (2018/2019). Głębokie uczenie radykalnie odmieni nasze interakcje z technologią. Harvard Business Review Polska, 12(1).

Smith, M.R., \& Marx, L. (1994). Does Technology Drives History. The Dilemma of Technological Determinism. Cambridge, MA: MIT Press.

Srivastava, R., Shervani, T., \& Fahey, L. (1998). Market-based assets and shareholder value: A framework for analysis. Journal of Marketing, 62(1). DOI: 10.2307/1251799.

Szymura-Tyc, M. (2006). Marketing we wspótczesnych procesach tworzenia wartości dla klienta i przedsiębiorstwa. Katowice: Wydawnictwo Akademii Ekonomicznej.

Urbanek, G. (2011). Kompetencje a wartość przedsiębiorstwa. Zasoby niematerialne w nowej gospodarce. Warszawa: Oficyna Wolters Kluwer Business.

Wiktor, J.W. (2018). Architektura systemu komunikacji wirtualnej - uwarunkowania i wyzwania. In: B. Gregor, D. Kaczorowska-Spychalska (red.), Marketing w erze technologii cyfrowych. Nowoczesne koncepcje $i$ wyzwania. Warszawa: Wydawnictwo Naukowe PWN.

Yadav, M.S., \& Varadarajan, P.R. (2005). Interactivity in the electronic marketplace: An exposition of the concept and implications for research. Journal of the Academy of Marketing Science, 33(4).

DOI: https://doi.org/10.1177/0092070305278487.

Żabiński, L. (red.), (1997). Analiza strategiczna przedsiębiorstwa na potrzeby wyboru strategii rozwoju (za pomoca metody SWOT). Katowice: Wydawnictwo Akademii Ekonomicznej. 